\title{
Evaluation of the mechanical properties of high-strength cement paste at elevated temperatures using metakaolin
}

\author{
Nabil Abdelmelek ${ }^{1} \cdot$ Eva Lubloy $^{1}$ (D) \\ Received: 27 September 2019 / Accepted: 23 June 2020 / Published online: 8 July 2020 \\ (c) The Author(s) 2020
}

\begin{abstract}
This paper presents a wide experimental study, in which it evaluates the performance of high-strength paste exposed to elevated temperatures up to $900{ }^{\circ} \mathrm{C}$. Several factors have been investigated at the age of 90 days, i.e. metakaolin (MK) dosages, water to binder ratio (w/b) as well as elevated temperatures. Results proved that MK improves the relative residual compressive strength and relative residual bending strength showing a gain up to $52 \%$ and of $71 \%$ at $500{ }^{\circ} \mathrm{C}$, respectively, compared to the pure cement paste in case of $0.3 \mathrm{w} / \mathrm{b}$. The maximum use of MK is not more than $12 \%$, and the optimum dosages were 9,12 , and $12 \%$ of MK replacements for $0.3,0.35$, and $0.4 \mathrm{w} / \mathrm{b}$, respectively. The optimum dosage could change with changing w/b ratio and this up to the density of the microstructure which is controlled by the amount of w/b ratio and the packing effect of MK amount. In addition to the mechanical properties, the adoption of MK decreases the cracking of the specimens at elevated temperatures. SEM investigations show the positive physical morphology contribution of MK, specific surface area as well as its chemical composition for decreasing the $\mathrm{Ca}(\mathrm{OH})_{2}$ effect. Different phases that formed during temperatures elevation are illustrated by TG analysis. Results showed the reason behind using MK on the cracking enhancement and mechanical properties improvement after high temperatures exposure. Meanwhile, the obtained optimum MK dosages at ambient temperature are not similar to that obtained at elevated temperatures.
\end{abstract}

Keywords Metakaolin $\cdot$ Elevated temperatures $\cdot$ High-strength cement paste $\cdot$ Water to binder $\cdot$ Supplementary cementitious materials

\section{Introduction}

Supplementary cementitious materials (SCMs) have been recently used in the concrete production in extensive level, to reduce the content of cement. The goal of using SCMs is to improve concrete performance such as mechanical properties, permeability, and durability of the cement paste. Many types of SCMs are available such as metakaolin (MK), fly ash, blast furnace slag, rice husk ash, and silica fume [1-5]. MK is widely used as SCMs or essential pozzolanic materials. One of the first usages of MK in cement production was in 1962 in Jupia Dam, Brazil. Around 250,000 metric

Eva Lubloy

lubloy.eva@epito.bme.hu

Nabil Abdelmelek

abdelmelek.nabil@epito.bme.hu

1 Department of Construction Materials and Technologies, Faculty of Civil Engineering, Budapest University of Technology and Economics, Budapest 1521, Hungary tonnes of MK have been used [6]. The main component of SCMs is the active amorphous $\mathrm{SiO}_{2}$ in which MK generally contains $50-55 \% \mathrm{SiO}_{2}$ in addition to $40-45 \%$ of $\mathrm{Al}_{2} \mathrm{O}_{3}$ [7]. Advantages of using MK are many. It enhances the concrete properties through its filler effect, pozzolanic activity with $\mathrm{Ca}(\mathrm{OH})_{2}$, and its contribution for accelerating the hydration of Ordinary Portland Cement (OPC) [8]. Kostuch et al. [1] as well as Poon et al. [8] reported that 10-15\% replacement of cement with $\mathrm{MK}$ reduced the $\mathrm{Ca}(\mathrm{OH})_{2}$ content in concrete by $70 \%$ at 28 -day testing age.

The interest of enhancing the concrete performance at elevated temperature has been raised up as a result of the extensive damages, partially or totally, especially high-rise buildings, tunnels, and many other structures [9]. Additionally, SCMs significantly enhance the concrete's resistance of aggressive environments exposure as well as fire accidents $[9,10]$. According to the fact that binder is one of the main ingredients that affect the mechanical behaviour of concrete exposed to elevated temperatures, significant importance has attributed to the SCMs including MK as used as replacement 
material of OPC [11-17]. High-strength paste (HSP) during fire is subjected to physical and chemical changes summarized in Table 1.

With respect to mechanical properties, Dinakar et al. [28] studied the effect of MK as binder on the mechanical properties of high-strength concrete with w/b of 0.3 . They used 5\% cement replacement interval up to $15 \%$. Results showed that $10 \%$ replacement was the optimum dosage. Khatib [29] studied the incorporation of MK up to $20 \%$ replacement in concrete with $0.3 \mathrm{w} / \mathrm{b}$. Using cement with $15 \%$ replacement of MK showed optimum results as far as compressive strength is concerned. From another perspective, El-Diadamony et al. [30] reported that pozzolanic cement paste having 5\% of MK dosage gives higher compressive strength values than other MK replacements. Justifying that 5\% MK acts as a nucleating agent increases the hydration rate of OPC.

By including temperature factor, Morsy et al. [31] evaluated the performance of mortars with and without MK exposed to elevated temperatures up to $800{ }^{\circ} \mathrm{C}$. Cement replacements from 5 to $30 \%$ of MK were used. Results concluded that MK improves the compressive strength before and after exposure to elevated temperature. The optimum MK replacement was $20 \%$. However, Poon et al. [8] by investigating the performance of MK exposed to elevated temperatures have relatively different results. Results declared that concrete with high replacement of MK (above $20 \%$ ) suffered high loss in strength at high temperatures as well as severe durability loss.
In general, the characteristics of MK refer to have a good indication for the future sustainable development of green concrete and high-performance behaviour. The results presented in this paper were performed for optimizing the dosage of MK replacement at a given w/b in cement paste exposed to elevated temperatures. Short incremental replacement that used in this research, i.e. 3\%, provided more accuracy to the results. In addition to that, comprehensive examination of the effect of different $w / b$ ratios on mechanical properties has been studied, including patterns of cracks and occurrence of spalling.

\section{Experimental}

An experimental program was made to evaluate the residual mechanical properties of MK cement paste. Major parameters of the study were MK (as replacement of cement), different temperature levels, and $\mathrm{w} / \mathrm{b}$ ratio $(0.3,0.35$, and $0.4)$ as shown in Table 2. In the experiment, the specimens were exposed to temperatures up to $900{ }^{\circ} \mathrm{C}$. The heating program was applied on the specimens for $2 \mathrm{~h}$ exposure on the target temperature and then naturally cooled down on chamber temperature at $20^{\circ} \mathrm{C}$ for $24 \mathrm{~h}$. The tests for residual compressive and bending strengths were carried out at the cold state in room temperature.

Table 1 General behaviour of hardened cement paste at temperatures

\begin{tabular}{|c|c|}
\hline Evaporation of water & $\begin{array}{l}\text { At } 105^{\circ} \mathrm{C} \text {, the hardened cement pastes totally loss the free water [18]. Further increasing to } 300^{\circ} \mathrm{C} \text {, the dehydration } \\
\text { of calcium silicates hydrate gel }(\mathrm{CSH}) \text { is occurred alongside sulpho-aluminate hydrate due to evaporation of water } \\
\text { between the hardened cement layers [19]. At } 400^{\circ} \mathrm{C} \text {, all the moisture in the capillaries pores is migrated out [20] }\end{array}$ \\
\hline Hydration products & $\begin{array}{l}\text { At } 110-150{ }^{\circ} \mathrm{C} \text {, the dehydration phases of ferric oxide, tri-sulphate and alumina, and mono-sulphate occur [21]. In } \\
\text { addition, the disintegration of portlandite or calcium hydroxide }\left(\mathrm{Ca}(\mathrm{OH})_{2}\right) \text { into lime }(\mathrm{CaO}) \text { and } \mathrm{H}_{2} \mathrm{O} \text { at } 400{ }^{\circ} \mathrm{C} \text { is } \\
\text { completed at about } 600{ }^{\circ} \mathrm{C} \text { [22]. } \mathrm{CSH} \text { gel bonds decompose from } 400{ }^{\circ} \mathrm{C} \text { till the total deterioration } 850{ }^{\circ} \mathrm{C}[19,23]\end{array}$ \\
\hline $\begin{array}{l}\text { Deterioration of } \\
\text { microstructure and } \\
\text { cracking }\end{array}$ & $\begin{array}{l}\text { Microcracks were started to appear in the hardened paste beyond } 100{ }^{\circ} \mathrm{C} \text { [24]. Hardened paste is exposed to expansion } \\
\text { contraction cycle till } 500{ }^{\circ} \mathrm{C} \text { [25]. This differential shrinkage is due to the movement of water vapours [26]. However, } \\
\text { microstructural deterioration occurs at elevated temperature as a result of the rising of porosity and enlargement of } \\
\text { the pore [27] }\end{array}$ \\
\hline
\end{tabular}

Table 2 Experimental matrix with detailed parameters

\begin{tabular}{|c|c|c|c|c|c|c|c|c|}
\hline $\begin{array}{l}\text { MK } \\
\text { dosages/\% }\end{array}$ & CEM I $42.5 \mathrm{~N}$ & Water & $\begin{array}{l}\text { MK } \\
\text { dosages/\% }\end{array}$ & CEM I $42.5 \mathrm{~N}$ & Water & $\begin{array}{l}\text { MK } \\
\text { dosages/\% }\end{array}$ & CEM I $42.5 \mathrm{~N}$ & Water \\
\hline \multicolumn{9}{|c|}{ Mixture proportion in $\mathrm{kg} / \mathrm{m}^{3}$} \\
\hline 0 & 480 & 144 & 0 & 480 & 168 & 0 & 480 & 192 \\
\hline 3 & 465.6 & 144 & 3 & 465.6 & 168 & 3 & 465.6 & 192 \\
\hline 6 & 451.2 & 144 & 6 & 451.2 & 168 & 6 & 451.2 & 192 \\
\hline 9 & 436.8 & 144 & 9 & 436.8 & 168 & 9 & 436.8 & 192 \\
\hline 12 & 422.4 & 144 & 12 & 422.4 & 168 & 12 & 422.4 & 192 \\
\hline 15 & 408 & 144 & 15 & 408 & 168 & 15 & 408 & 192 \\
\hline
\end{tabular}




\section{Materials}

Ordinary Portland Cement (CEM I 42,5 N) was used in this program to study purely the performance of MK on the properties of the HSP and to eliminate the effect of mineral admixtures. Portland cement was supplied from Hungarian company (Duna-Dráva Cement Heidelbergcement Group). The sieve curve for the cement is shown in Fig. 1. The chemical composition and physical characteristic of cement and MK are given in Table 3. Tests were carried out in compliance with European standards, MSZ EN 196-2 and BS EN 525-12 [32-34].

Metakaolin used herein was obtained from Newchem Company, Hungary, as a type of Metaver N. It is a primary material with attractive white colour, made by calcinations of natural kaolin at a typical temperature range of 600-800 ${ }^{\circ} \mathrm{C}$. It reacts with $\mathrm{Ca}(\mathrm{OH})_{2}$ forming soluble $\mathrm{CSH}$ phases. The XRD of MK is studied, and results show a total amorphous content of $94.6 \%$. Metaver N follows MSZ 4798: (2015) [35]. Typical particle distribution was studied by laser granulometer method, due to the high surface area of the particle, where from 7 to $9 \%$ of the total volume is less than $1 \mu \mathrm{m}, 50 \%$ of the volume passes through $3.4-4.5 \mu \mathrm{m}$ sieve size, and $95 \%$ of the passing takes place between 12 and $18 \mu \mathrm{m}$ sieve sizes. This indicates that the used MK in this program is very fine compared to CEM I $42.5 \mathrm{~N}$ particles.

The chemical compositions of the used MK greatly influence the mechanical as well as physical behaviour. Additionally, it has significant impact on durability, especially the proportion of the three main oxides $\left(\mathrm{SiO}_{2}, \mathrm{CaO}\right.$, and $\mathrm{Al}_{2} \mathrm{O}_{3}$ ) shown in Fig. 2 and Table 3. In addition, the presence of other compounds is not less importance, i.e. $\mathrm{Fe}_{2} \mathrm{O}_{3}$ which decreased specimen's loss in compression and mass after heating. Moreover, it is beneficial in segmenting the crack elongation and filling the large pores which is valuable for bending resistance [36]. Farzadnia et al. [37] found that titanium $\left(\mathrm{TiO}_{2}\right)$ improved the residual strength after high

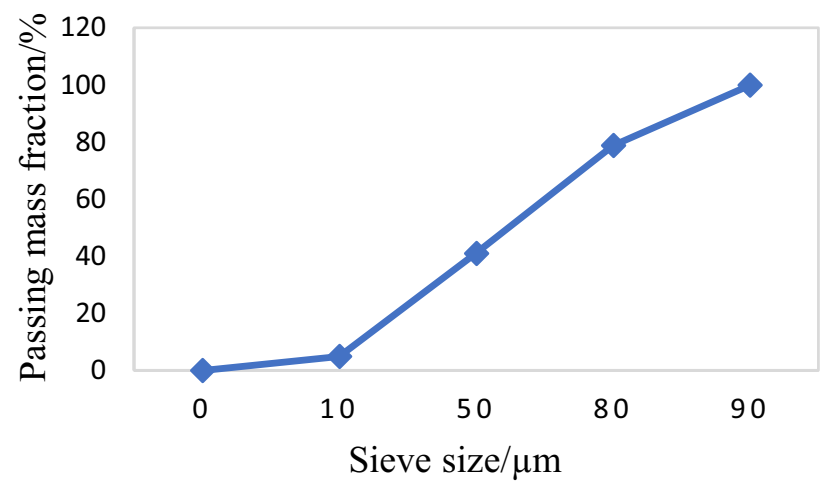

Fig. 1 Grading curves of cement
Table 3 Chemical composition and physical characteristics of tested cement and MK

\begin{tabular}{|c|c|c|}
\hline Measured property & CEM I & MK \\
\hline Density $/ \mathrm{g} \mathrm{cm}^{-3}$ & 3.13 & 2.6 \\
\hline Specific surface area/cm $+2 \mathrm{~g}^{-1}$ & 4000 & 24,000 \\
\hline \multicolumn{3}{|l|}{ Oxide compositions/\% (by mass) } \\
\hline $\mathrm{SiO}_{2}$ & 19.84 & $52-53$ \\
\hline $\mathrm{Al}_{2} \mathrm{O}_{3}$ & 5.38 & $43-44$ \\
\hline $\mathrm{Fe}_{2} \mathrm{O}_{3}$ & 3.22 & $<1$ \\
\hline $\mathrm{Ca} 0$ & 64.90 & $<0.5$ \\
\hline $\operatorname{Mg} 0$ & 1.38 & $<0.4$ \\
\hline $\mathrm{SO}_{3}$ & 2.97 & - \\
\hline $\mathrm{K}_{2} \mathrm{O}$ & 0.78 & $<1$ \\
\hline $\mathrm{Cl}$ & 0.0048 & - \\
\hline $\mathrm{Na}_{2} \mathrm{O}$ & - & $<0.1$ \\
\hline $\mathrm{TiO}_{2}$ & - & $<1$ \\
\hline Loss on ignition & 3.0 & 1.59 \\
\hline
\end{tabular}

temperatures exposure [38]. A dosage of $2 \mathrm{~g} / \mathrm{kg}$ of liquid superplasticizer (GLENIUM ${ }^{\circledR}$ C 300 (AT)) was applied for each mix.

\section{Curing and heating program}

Efficiency of specific amounts of MK has been taken into considerations herein, so the way of mixing is important in this study. The dry binder (cement $+\mathrm{MK}$ ) was mixed for $30 \mathrm{~s}$ to ensure homogenous binder distribution. All amounts of water with superplasticizer were then added and mixed with three-quarter amounts of binders. In addition, the remaining amount was added during the mixing to remove lumps and ensure water reaches binder particles. Two minutes of mixing duration was followed by 1-min rest period to scrape off any unmixed powders from the paddle sides of the mixer and adding them into the mixing bowl. After that, the fresh paste was poured into $30 \mathrm{~mm}$ cubes and $40 \times 40 \times 160 \mathrm{~mm}$ prisms

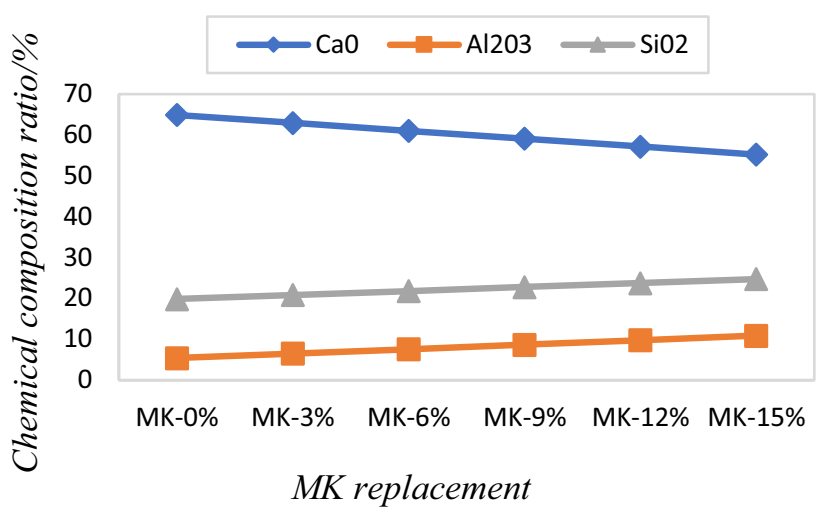

Fig. 2 The ratio of the three main oxides for each mixture 
(24 cubes and 24 prisms per mixture) vibrated for $1 \mathrm{~min}$ to release air bubbles content. The specimens were demoulded $24 \mathrm{~h}$ after the casting. After 7 days of curing in water tank, the specimens were taken out in an air-conditioned chamber maintained at $20 \pm 2{ }^{\circ} \mathrm{C}$ and $65 \pm 5 \%$ relative humidity. The parameter combinations have resulted in 18 mixtures as shown in Table 2, to reach altogether 864 specimens (432 prisms and 432 cubs). Each mixture is comprised of eight groups based on temperatures. At the age of 90 days after casting, the first group was tested directly in ambient temperature to determine the strength after curing. All groups were tested after exposure to the target temperature, and the target temperatures are $50{ }^{\circ} \mathrm{C}, 150{ }^{\circ} \mathrm{C}, 300{ }^{\circ} \mathrm{C}, 400{ }^{\circ} \mathrm{C}$, $500{ }^{\circ} \mathrm{C}, 800{ }^{\circ} \mathrm{C}$, and $900{ }^{\circ} \mathrm{C}$, respectively. The mechanical properties were tested, according to the Réunion Internationale des Laboratoires et Experts des Matériaux (RILEM) recommendation, at the age of 90 days [39]. The reason to test at this age is to increase the amount of hydration products such as $\mathrm{CSH}, \mathrm{CAH}$, and calcium aluminate silicate hydrates (CASH) [40].

Then, the specimens were heated in an electrical furnace. The heating curve was similar to the standard fire curve ISO 834 for buildings up to $800{ }^{\circ} \mathrm{C}$ [41], which is shown in Fig. 3 and then naturally cooled down in laboratory conditions. Residual strengths were measured for specimens, and then, the average values of the measurements were analysed.

Compressive and bending strength tests were conducted on hardened cement paste specimens with a loading rate of $1.40 \mathrm{kN} \mathrm{s}^{-1}$ and $0.06 \mathrm{kN} \mathrm{s}^{-1}$, respectively. The tests are conducted in laboratory condition $\left(20 \pm 2{ }^{\circ} \mathrm{C}\right)$ using ALPHA $3 / 3000 \mathrm{~S}$ test machine with capacity of 200 and $10 \mathrm{kN}$ for compressive and bending stress, respectively.

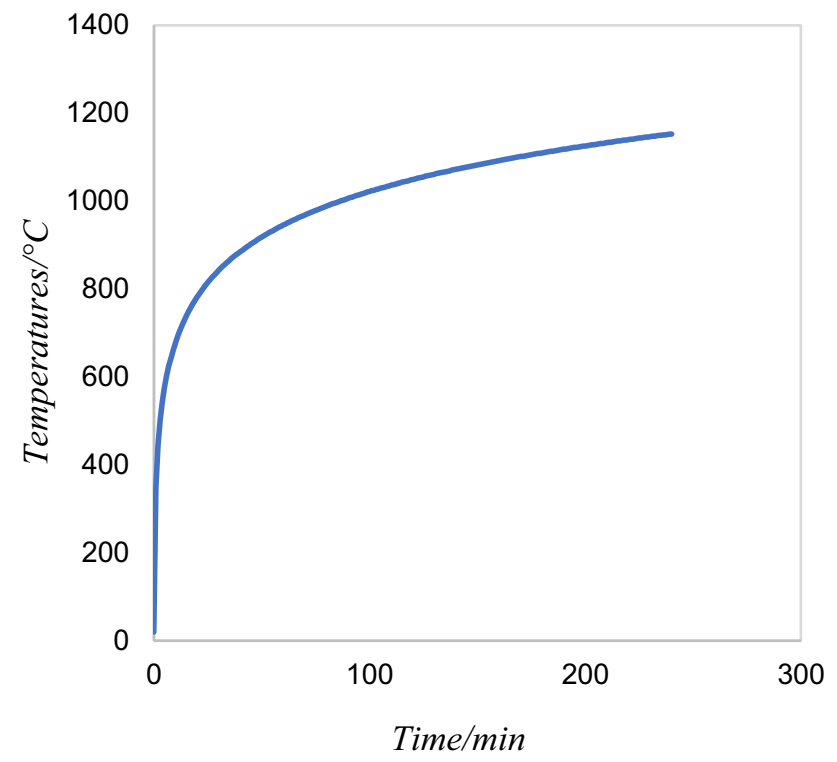

\section{Thermogravimetric program}

TG investigation defines the ranges of various thermal decompositions of different paste products and phases with simultaneous estimation of the mass loss in static condition. Moreover, changes in phases are controlled by TG/DTG/ DTA serves and using MOM Derivatograph-Q 1500 D TG/ DTA instrument. During the measurements, $\mathrm{Al}_{2} \mathrm{O}_{3}$ is the reference material and the mass of sample is $300 \mathrm{mg}$. The heating rate of samples was $10{ }^{\circ} \mathrm{C} \mathrm{min}-1$ up to $1000{ }^{\circ} \mathrm{C}$ in air atmosphere.

TG samples are grinded to fine powder measured by TG/ DTA, to ensure the soundness of samples from carbonation due to the airborne $\mathrm{CO}_{2}$, and the grinded powders were selected from the core of specimens. The thermo-analytical test results are determined by Winder (version 4.4.) software. The tested powders were taken from specimens of ambient temperatures $20^{\circ} \mathrm{C}$. The investigated powders are for all mixtures with $0.35 \mathrm{w} / \mathrm{b}(0,3,6,9,12$, and $15 \%$ of MK). The TG/DTA studies were carried out when sample had an age of 90 days.

\section{Scanning electron microscope (SEM)}

Scanning electron microscope investigations have helped to discover and understand the microstructure of hardened cement paste with and without MK before and after the exposure to high temperatures in addition to the morphological properties of the powder. After the compressive strength test, the core of the cross-sectional areas of the specimen was coated with gold for $30 \mathrm{~s}$ and then observed under Phenom XL SEM. However, it is important to get enough information about the evolution of the microstructure due to pozzolanic materials.

\section{Results and discussion}

\section{Results at ambient temperature}

\section{Cement and MK morphology}

Figure 4 shows the microstructure of the used cement and MK was investigated by SEM and the picture was taken at high magnification of $2000 \times$. The size and shape of the particles of MK differ than of cement. MK is a very fine material characterized by elongated shape like fibres which could promise a good performance of hardened paste at ambient and elevated temperatures. Knowing the morphology and microstructure of powders helps understand the behaviour of cement paste at high temperatures.

Fig. 3 ISO-834 fire curve 
Fig. 4 Microstructure morphology of the used cement and MK by SEM

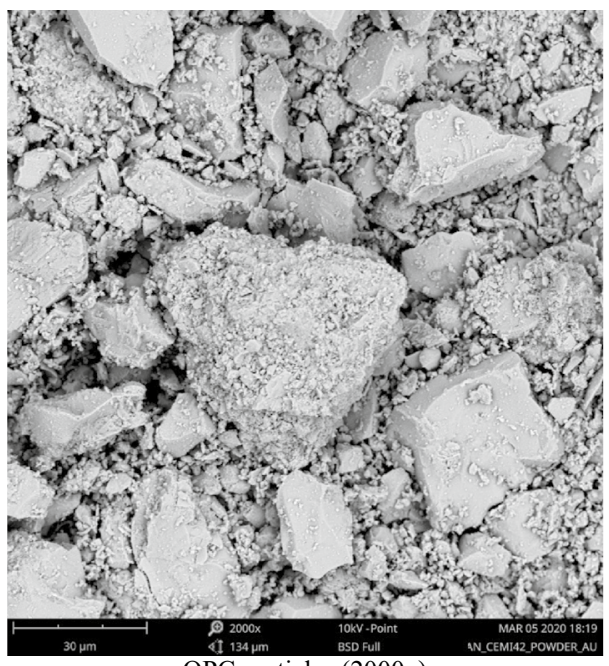

OPC particles $(2000 \mathrm{x})$

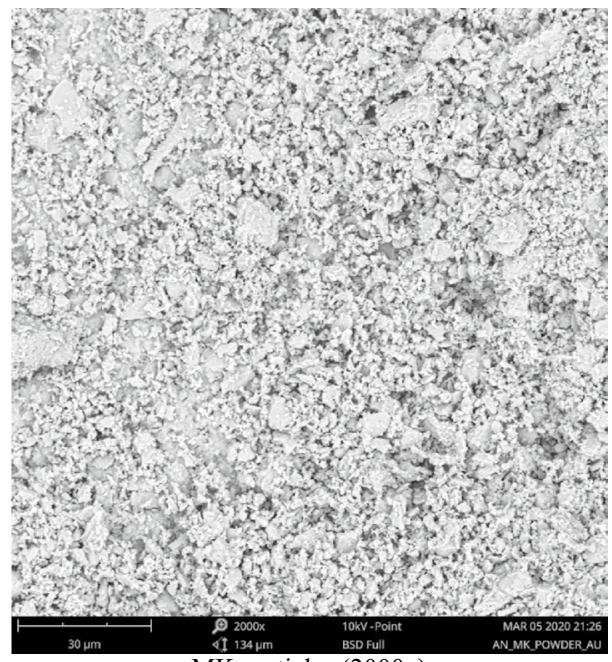

MK particles (2000x)

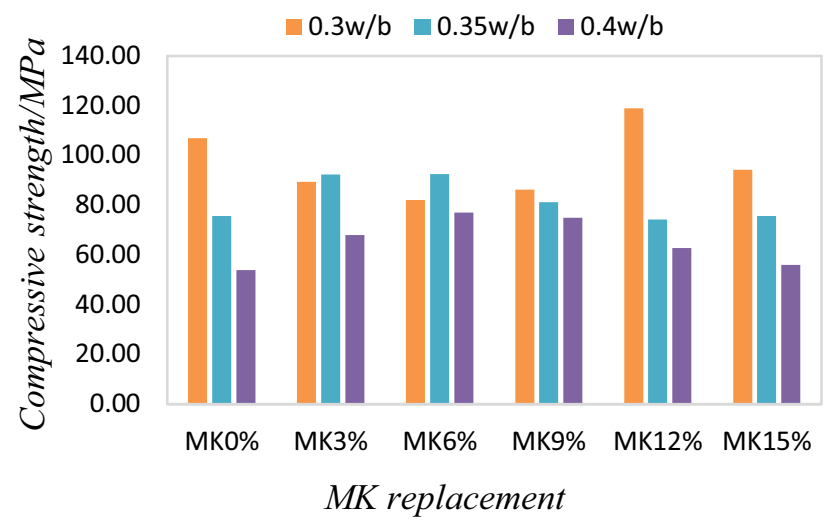

Fig. 5 Compressive strength of different MK replacement with respect to $\mathrm{w} / \mathrm{b}$ ratio

\section{Compressive strength}

Different properties of HSP mixed with MK depend mainly on many factors, such as w/b ratio, properties of MK, mixing program and procedures, initial cement content, the amount and type of plasticizers, and other admixtures. Compressive strength is the most investigated property and basic indicator of materials durability and performance. The compressive strength values of HSP specimens are graphically represented as a function of MK replacements in Fig. 5. The exact definition of high strength in terms of numerical values is not clear and without a sound reason [42]. However, American Concrete Institute (ACI) ACI 363R-9200 gives a description for high-strength concrete in the updated draft with a compressive strength greater than $55 \mathrm{MPa}$ as high strength [43]. Thus, the results in this study are high strength.

By using $0.3 \mathrm{w} / \mathrm{b}$ ratio, the mixture that contains $12 \%$ of MK, with a compressive strength of $118.94 \mathrm{MPa}$, has exhibited the highest compressive strength compared to the other MK replacements. Thus, $12 \%$ of MK can be considered as an optimum replacement as far as the compressive strength is concerned. This is slightly less than the replacement level of $15 \%$ reported in a previous study for the same w/b ratio of 0.30 [29]. However, at the current study mixtures with $15 \%$ of MK show less strength compared to $12 \%$ of MK. This could be attributed to the clinker amount effect. The amount effect is a result of replacing part of cement by the equivalent quantity of MK from the perspective of cement reaction and from the availability of $\mathrm{Ca}(\mathrm{OH})_{2}$. Metakaolin develops the strength by pozzolanic reaction. It could be also due to the higher surface area of MK resulting in more nucleation sites to increase reactivity rate and improve packing effect as well as increasing the interfacial zone between cement particles.

Figure 5 also shows that efficiency of MK amount of mixtures with more than $6 \%$ of MK starts to decrease by the virtue of dilution effect for mixtures prepared with 0.35 and $0.4 \mathrm{w} / \mathrm{b}$. On the other hand, mixtures with $0.3 \mathrm{w} / \mathrm{b}$ reached $12 \%$ rather than $6 \%$. Suggested interpretation is that at low $\mathrm{w} / \mathrm{b}$ the additional amount of MK is working as a filler material, thus increasing the strength by activating the extra amount of MK as filler as shown in Fig. 6. The effectiveness of packing effect on strength is clear at very low w/b unlike high w/b which needs more MK replacement. However, at high w/b the contribution of the extra MK becomes less efficient due to the increase in porosity, where the addition of more MK replacement to achieve the purpose becomes limited by the clinker dilution effect [28].

In order to express the development of the pozzolanic activity of MK with cement for the three w/b, the ratio between the compressive strengths of specimens should be calculated by dividing compressive strength of optimum dosage to the compressive strength of the $0 \%$ MK for each 


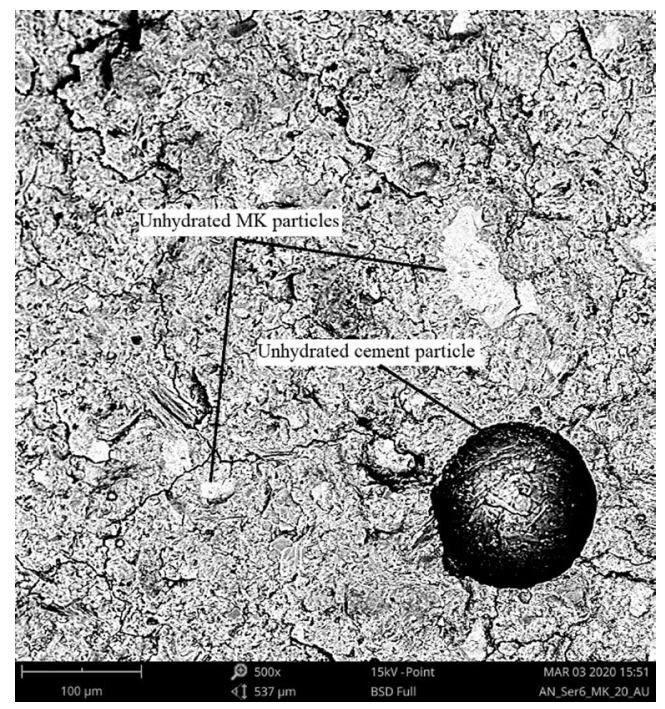

Fig. 6 The unhydrated particles in the hardened cement paste with $0.3 \mathrm{w} / \mathrm{b}$

w/b. The pozzolanic action has been determined, and the calculated values are summarized in Fig. 7. It is clear that by increasing water content the pozzolanic activity for the optimum dosages is increased.

\section{Results after temperature loading}

Specimens showed different performances with respect to surface cracking and residual strength after exposing to high temperatures. This study is mainly concerned with high temperatures particularly between 500 and $800{ }^{\circ} \mathrm{C}$.

\section{Surface cracking}

Specimens during temperature loading undergo chemical and physical changes leading to surface cracks. Developing surface cracks as a result of the elevated temperatures is presented in Fig. 8. There were no macroscopic observable changes on the cubes surface up to maximum temperature $400{ }^{\circ} \mathrm{C}$. This observation is also valid for specimens with $0 \%$ MK. However, the number and size of cracks strongly grew with heating up to $900{ }^{\circ} \mathrm{C}$ for mixtures with $0 \% \mathrm{MK}$. The more the amount of MK, the less the number of cracks. From the other hand, specimens with low w/b show less cracks than specimens with higher $\mathrm{w} / \mathrm{b}$ at the same MK levels. That is obvious at high temperatures, i.e. $800{ }^{\circ} \mathrm{C}$. On contrast, specimens with low $\mathrm{w} / \mathrm{b}$ are more prone to sudden spalling. After cooling down, more cracks are noticed in the surface of specimens. The reason for this phenomenon is rehydration of $\mathrm{CaO}$ could considerably increase the extent of the crack development with further changes in volume.

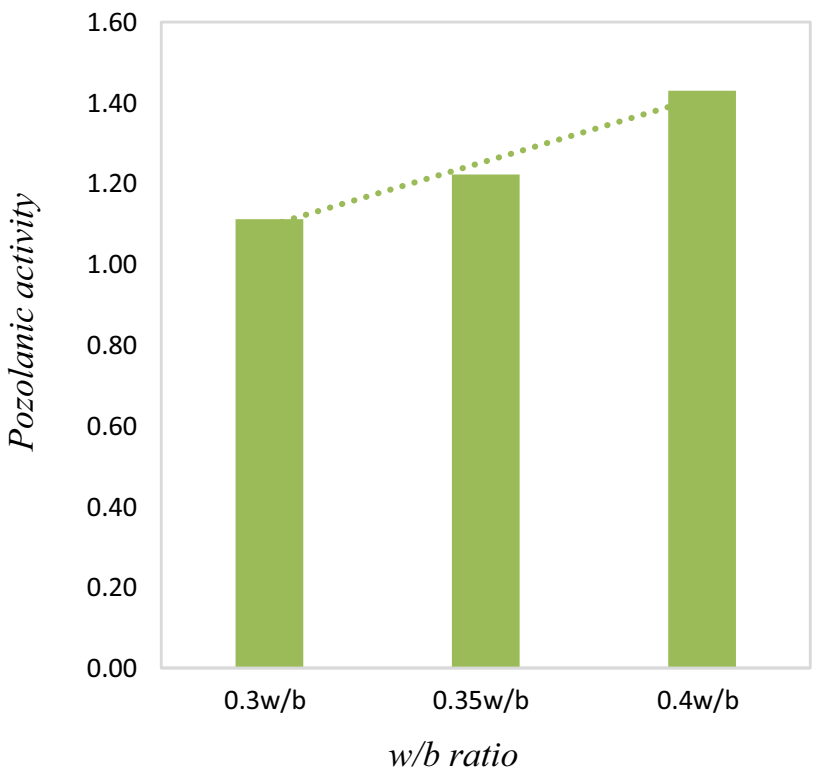

Fig. 7 Pozzolanic activity of the optimum mixture for each $w / b$ ratio

\section{Compressive strength}

Effect of MK The results of the compressive strength tests are considered as the average of three measurements and given in the form of relative residual compressive strength (RRCS) (Figs. 9-11). RRCS is the ratio of compressive strength at different levels of elevated temperatures to compressive strength at $20{ }^{\circ} \mathrm{C}$. The values of compressive strength results are consistent. The standard deviation values are summarized in Table 4.

RRCS is slightly decreased when the temperature is increased; this decrease continues up to $400{ }^{\circ} \mathrm{C}$. After $400{ }^{\circ} \mathrm{C}$, the RRCS of some specimens (Fig. 9) decreases significantly.

The RRCS of specimens without MK for 0.3, 0.35, and $0.4 \mathrm{w} / \mathrm{b}$ after exposure to $500{ }^{\circ} \mathrm{C}$ are 24,55 , and $43 \%$, respectively. Further increasing temperature up to $800{ }^{\circ} \mathrm{C}$, the specimens are still coherent and RRCS is 21,51 , and $22 \%$ for $0.3,0.35$, and $0.4 \mathrm{w} / \mathrm{b}$, respectively. Figure 9 shows the development of RRCS for all mixtures with $0.3 \mathrm{w} / \mathrm{b}$, and the tendency of RRCS with all temperature levels is almost similar. Most of the curves begin to slightly decrease after $50{ }^{\circ} \mathrm{C}$. Yet, some mixtures start to show sharp degrading after $400{ }^{\circ} \mathrm{C}$ (Fig. 9).

Moreover, MK content has a significant influence on RRCS. By comparing various types of the studied mixtures, it can be clearly observed that the mixture that contains $9 \%$ of MK shows the highest RRCS (76\%) among the other five mixtures at $500{ }^{\circ} \mathrm{C}$ with a slight reduction in the relevant RRCS at $800{ }^{\circ} \mathrm{C}$ to reach $60 \%$. 
$w / b$
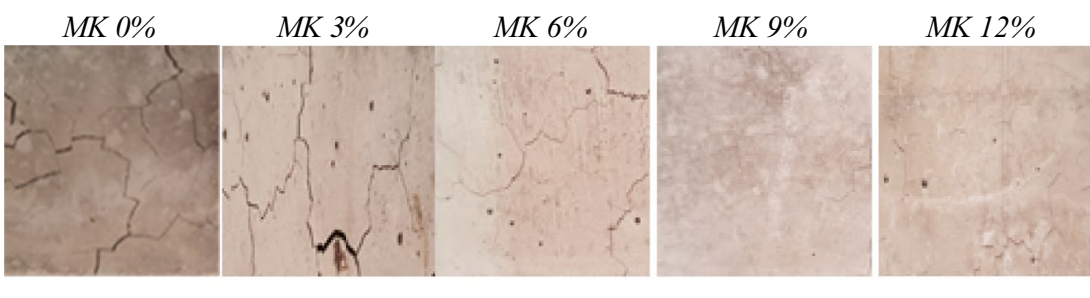

MK $15 \%$

0.3
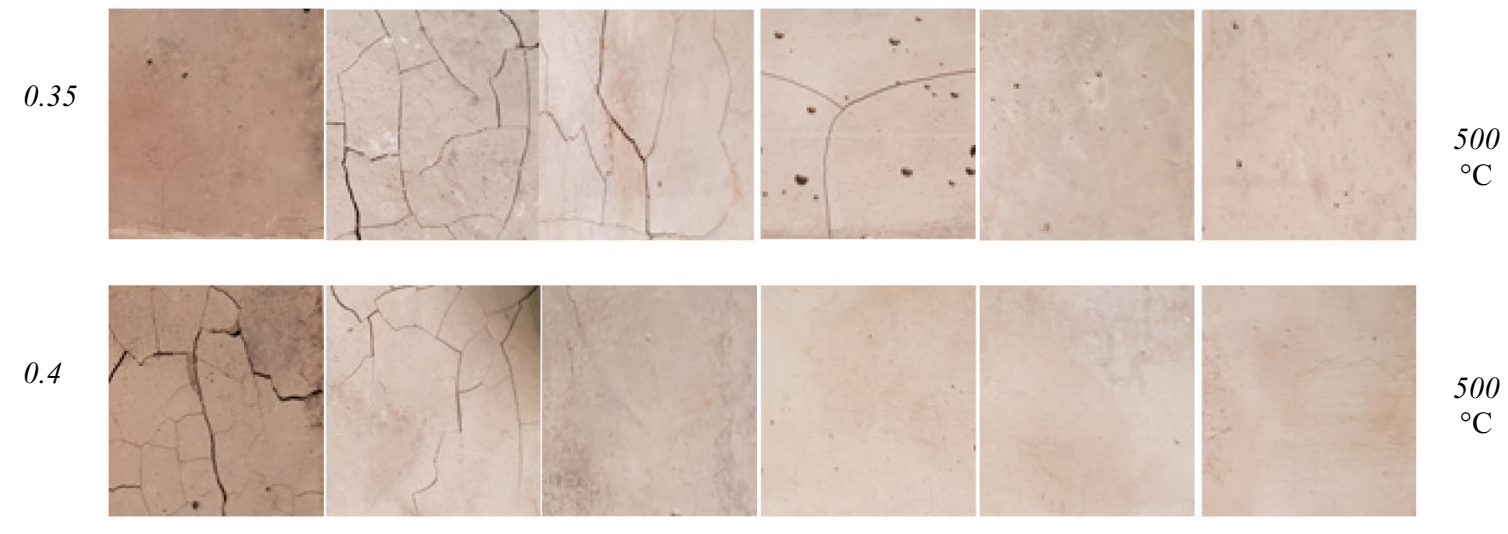

500

${ }^{\circ} \mathrm{C}$
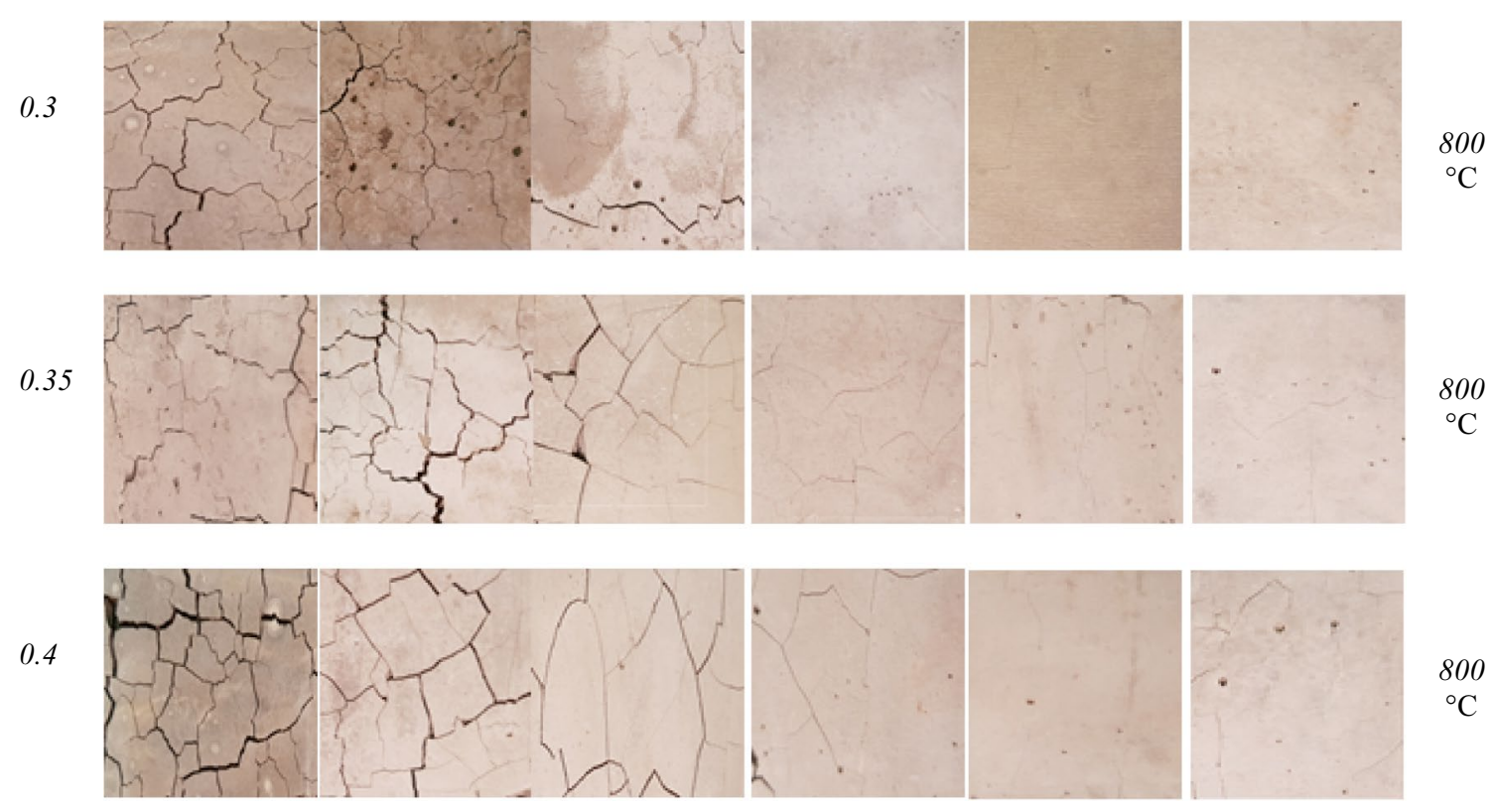

Fig. 8 Effect of MK dosages and w/b ratio on the development of surface cracks as a result of the elevated temperature (scale of photo $x=30 \mathrm{~mm}, y=30 \mathrm{~mm}$ )

In case of $0 \% \mathrm{MK}$, specimens suffer more after $400{ }^{\circ} \mathrm{C}$ exposure, whereas the RRCS of the other mixtures is increased by increasing MK content. The intensity of $\mathrm{Ca}(\mathrm{OH})_{2}$ is decreased as MK amount increases, and this could be a part of the reason why RRCS of MK 9\% is higher than the others, in which the $\mathrm{Ca}(\mathrm{OH})_{2}$ acts as the arrow that destroys the mechanical and physical properties of hardened cement at elevated temperatures.

Notwithstanding, specimens with higher replacement of MK exhibit a considerable loss in strength after exposure to elevated temperatures. This could be due to high dense microstructure, clinker dilution effect, or heating rate $[7,8$, 19, 20]. Poon et al. [8] investigated the porosity by using mercury intrusion porosimetry method proposing that MK densifies the microstructure at higher temperatures, suggesting also that the high dense microstructure as a reference to the high surface area leads to form large pore area fraction at high temperatures in the presence of vapour. Furthermore, increase in pore pressure induces internal cracks. 


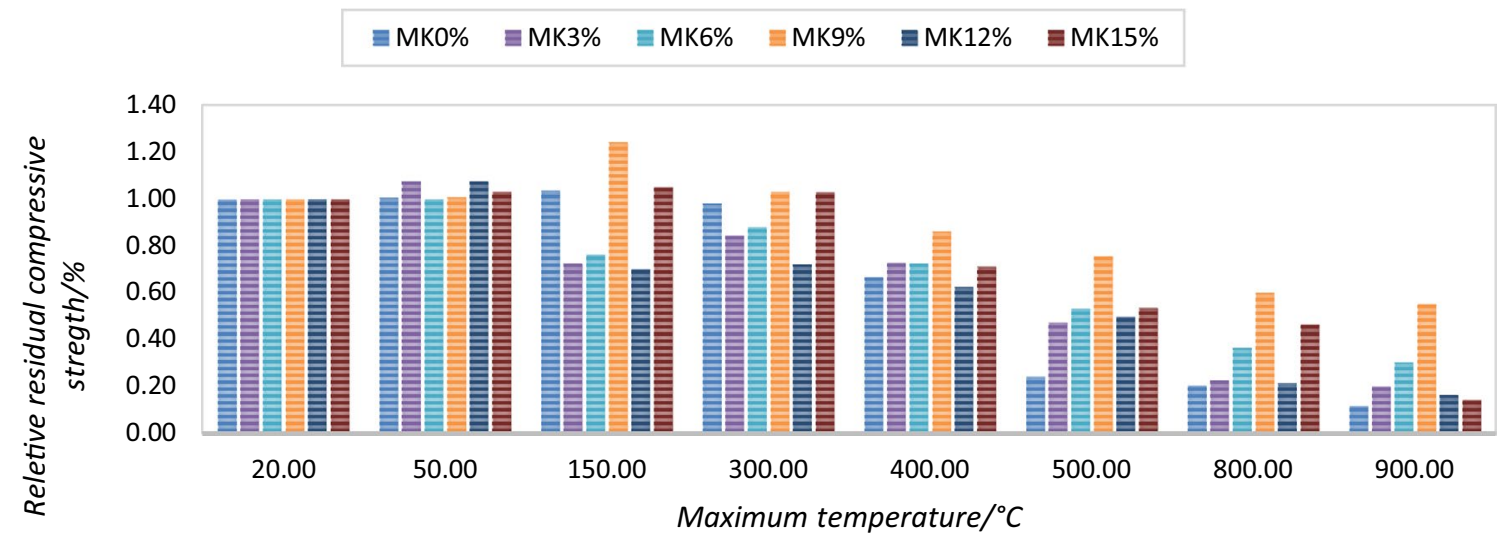

Fig. 9 Relative residual compressive strength as a function of temperature of HSP incorporated with MK of $0.3 \mathrm{w} / \mathrm{b}$

All mixtures with $0.35 \mathrm{w} / \mathrm{b}$ ratio and containing $9 \%, 12 \%$, and $15 \%$ of $\mathrm{MK}$ at $500{ }^{\circ} \mathrm{C}$ show RRCS of $73 \%, 88 \%$, and $74 \%$, respectively. After heating up to $800^{\circ} \mathrm{C}$, the RRCS for the same mixtures decreases smoothly to 51,64 , and $53 \%$, respectively. Figure 11 presents the results of all mixtures with $0.40 \mathrm{w} / \mathrm{b}$, and MK with $12 \%$ replacement shows less loss in RRCS compared to the other mixtures. The average of the RRCS for the same mixtures was $64 \%$ by heating up to $500{ }^{\circ} \mathrm{C}$ and further $54 \%$ by heating up to $800{ }^{\circ} \mathrm{C}$.

From another hand, microcracks are formed on mixtures that contain high amount of MK, because of the high specific surface area of MK (fineness) which decreases the amount of water in addition to the filling effect leading to discontinuity of pores (pore-blocking effect) and dense microstructure, which could adversely affect the microstructure at elevated temperature by the vapour pressure effect [8, 19, 44, 45]. Inversely, the increase in w/b work opposite of MK increases the porosity and allows the increase in MK amount, suggesting that why MK $12 \%$ was optimum for mixtures with 0.35 $\mathrm{w} / \mathrm{b}$, whereas it was shifted to $9 \%$ for mixtures with $0.3 \mathrm{w} / \mathrm{b}$.
Effect of w/b Behaviour of MK on different w/b after high temperatures is an important objective of this study. Results of changing $\mathrm{w} / \mathrm{b}$ ratio on hardened paste on the mechanical behaviour are quite well known particularly in compression, but still lack of study is present on the incorporation of MK at elevated temperatures. W/b ratio has a great impact on HSP which governs the porosity and heavily influences the behaviour [46-48]. The optimization has been done by the comparison on each specific amount of MK using compression and cracks propagation as shown in Figs. 12 and 13. The changes of strengths are caused by the changing in the w/b between the three mixtures, which is clearly large up to $400{ }^{\circ} \mathrm{C}$ and more pronounced with $0.3 \mathrm{w} / \mathrm{b}$ ratio. After $400{ }^{\circ} \mathrm{C}$, mixtures with $0.3 \mathrm{w} / \mathrm{b}$ show more strength loss as well as mixtures for $0.4 \mathrm{w} / \mathrm{b}$, as shown in Fig. 12. Yet, mixtures of $0.35 \mathrm{w} / \mathrm{b}$ show better results.

Results prove that the variations in strength between mixtures with same MK replacement (15\% MK) are depending on $w / b$ ratio. This variation starts to decrease at higher temperature exposures. Compressive strength results show

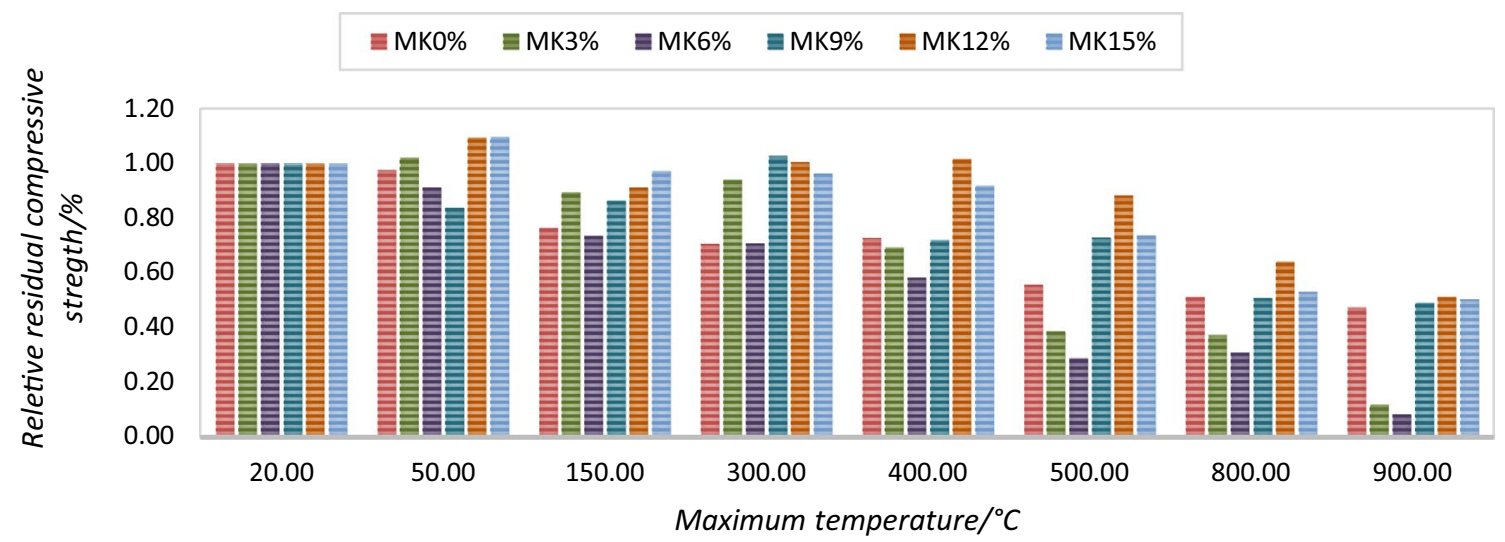

Fig. 10 Relative residual compressive strength as a function of temperature of HSP incorporated with MK of 0.35 w/b 


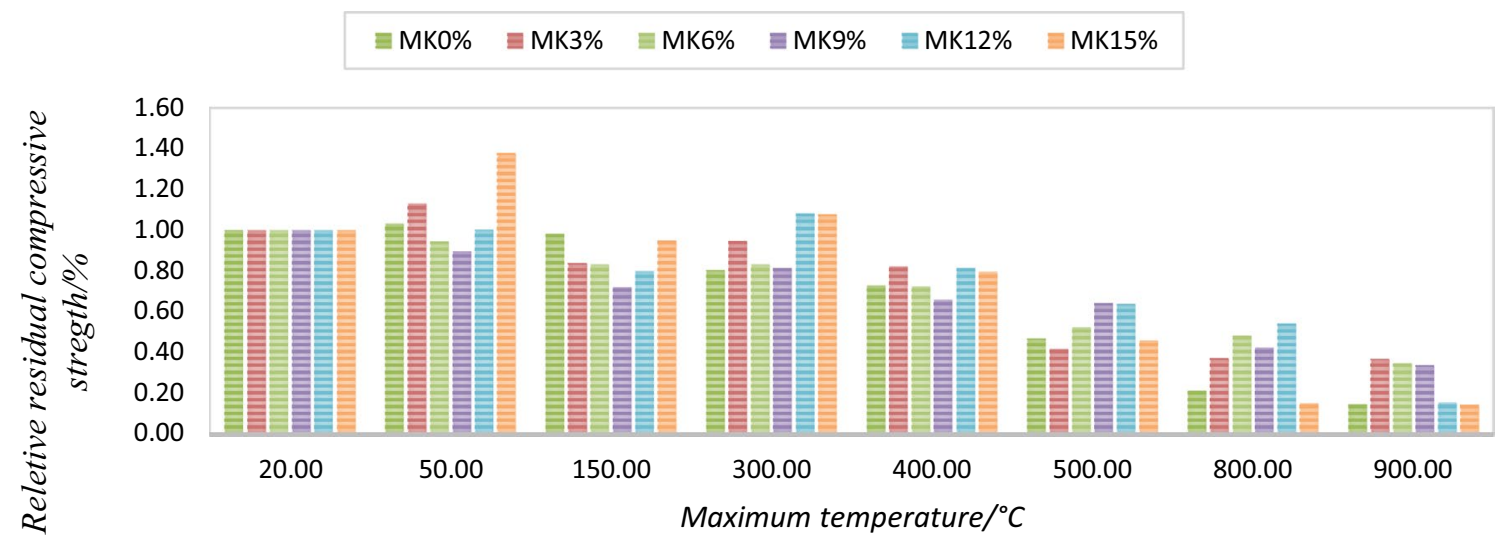

Fig. 11 Relative residual compressive strength as a function of temperature of HSP incorporated with MK of 0.4 w/b

that from 20 to $400{ }^{\circ} \mathrm{C}$, values are higher with $0.3 \mathrm{w} / \mathrm{b}$ than others. Beyond $400{ }^{\circ} \mathrm{C}$, both 0.3 and 0.35 show rather similar results.

To sum up the results, RRCS results are in accordance with crack patterns developments. The highest number and most remarkable cracks are present in the specimens prepared with pure OPC and high w/b ratio where the RRCS loss was the highest as well. After heating, the RRCS of cement paste is significantly increased at specific amount of MK. According to the optimization used herein, the strength losses of those optimum dosages of the three $w / b$ are different from each other, as shown in Fig. 14.
Table 4 Standard deviation of compressive strength values

\begin{tabular}{|c|c|c|c|c|c|c|}
\hline & MK 0\% & MK 3\% & MK 6\% & MK 9\% & MK $12 \%$ & MK $15 \%$ \\
\hline \multicolumn{7}{|l|}{$0.3 \mathrm{w} / \mathrm{b}$} \\
\hline $20^{\circ} \mathrm{C}$ & 2.11 & 1.93 & 2.88 & 1.76 & 1.92 & 1.44 \\
\hline $50^{\circ} \mathrm{C}$ & 0.88 & 0.69 & 3.12 & 2.35 & 0.85 & 3.31 \\
\hline $150^{\circ} \mathrm{C}$ & 0.04 & 5.01 & 4.81 & 1.6 & 0.85 & 2.99 \\
\hline $300^{\circ} \mathrm{C}$ & 0.6 & 3.3 & 4.51 & 5.86 & 4.88 & 0.53 \\
\hline $400{ }^{\circ} \mathrm{C}$ & 3.36 & 0.77 & 4.18 & 3.85 & 0.17 & 2.37 \\
\hline $500{ }^{\circ} \mathrm{C}$ & 3.33 & 5.33 & 3.38 & 1.13 & 3.80 & 3.23 \\
\hline $800^{\circ} \mathrm{C}$ & 1.6 & 2.26 & 0.81 & 4.91 & 1.62 & 3.96 \\
\hline $900{ }^{\circ} \mathrm{C}$ & 1.68 & 0.59 & 3.15 & 0.49 & 1.51 & 1.46 \\
\hline \multicolumn{7}{|l|}{$0.35 \mathrm{w} / \mathrm{b}$} \\
\hline $20^{\circ} \mathrm{C}$ & 0.68 & 1.45 & 0.49 & 2.67 & 1.23 & 1.91 \\
\hline $50^{\circ} \mathrm{C}$ & 2.93 & 4.62 & 5.47 & 2.46 & 0.23 & 3.06 \\
\hline $150^{\circ} \mathrm{C}$ & 0.21 & 5.36 & 3.84 & 0.02 & 1.99 & 2.86 \\
\hline $300^{\circ} \mathrm{C}$ & 2.77 & 5.74 & 1.46 & 0.52 & 5.40 & 0.55 \\
\hline $400{ }^{\circ} \mathrm{C}$ & 1.2 & 0.15 & 0.18 & 2.59 & 2.50 & 2.25 \\
\hline $500{ }^{\circ} \mathrm{C}$ & 3.98 & 4.34 & 1.70 & 1.45 & 3.84 & 2.23 \\
\hline $800^{\circ} \mathrm{C}$ & 2 & 2.01 & 0.69 & 4.3 & 0.95 & 4.20 \\
\hline \multicolumn{7}{|l|}{$0.4 \mathrm{w} / \mathrm{b}$} \\
\hline $20^{\circ} \mathrm{C}$ & 3.67 & 1.62 & 1.12 & 1.55 & 2.86 & 0.92 \\
\hline $50{ }^{\circ} \mathrm{C}$ & 3.14 & 2.80 & 0.15 & 1.98 & 2.41 & 4.34 \\
\hline $150^{\circ} \mathrm{C}$ & 1.15 & 2.87 & 1.15 & 0.76 & 3.93 & 3.99 \\
\hline $300{ }^{\circ} \mathrm{C}$ & 1.60 & 5.28 & 1.53 & 2.00 & 3.27 & 4.07 \\
\hline $400{ }^{\circ} \mathrm{C}$ & 5.58 & 2.90 & 1.81 & 0.21 & 0.45 & 2.19 \\
\hline $500{ }^{\circ} \mathrm{C}$ & 2.92 & 0.13 & 3.19 & 0.54 & 2.84 & 0.21 \\
\hline $800{ }^{\circ} \mathrm{C}$ & 0.86 & 1.66 & 2.34 & 0.91 & 3.29 & 3.16 \\
\hline $900{ }^{\circ} \mathrm{C}$ & 1.4 & 2.79 & 1.22 & 0.70 & 2.11 & 0.64 \\
\hline
\end{tabular}




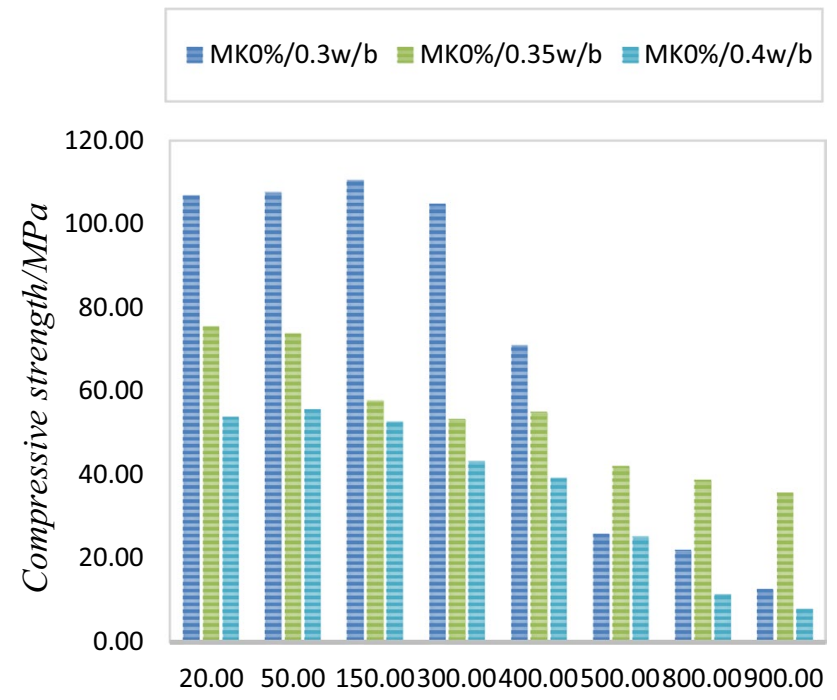

Maximum temperatures $/{ }^{\circ} \mathrm{C}$

Fig. 12 Compressive strength of mixtures without MK for the three $\mathrm{w} / \mathrm{b}$ as a function of temperature

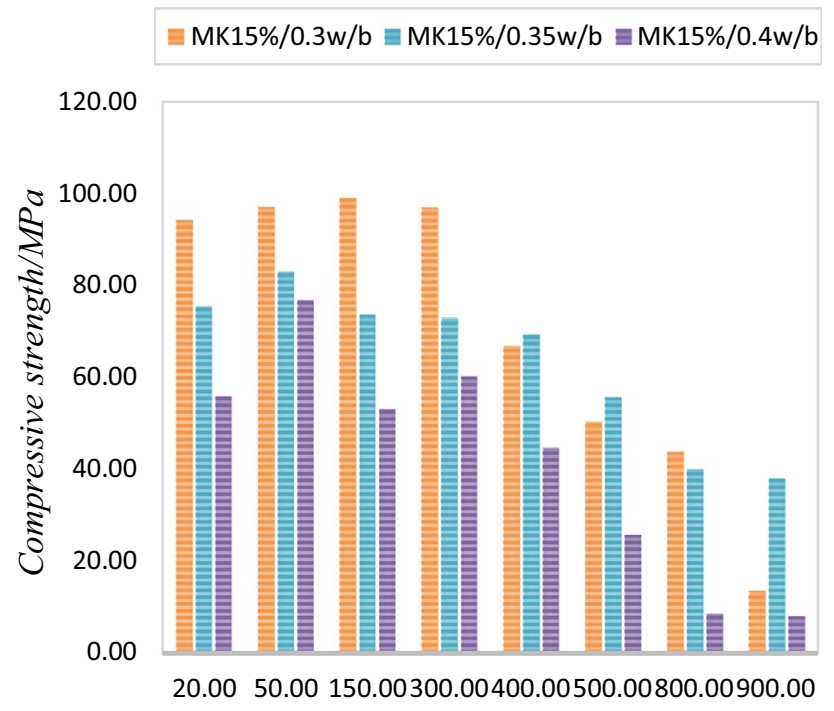

Maximum temperatures $/{ }^{\circ} \mathrm{C}$

Fig. 13 Compressive strength of mixtures with $15 \%$ of MK for the three $w / b$ as a function of temperature

\section{Bending strength}

Developments of the bending strength results as a function of MK replacement at ambient temperature are presented in Table 5. Prisms under bending load are sensitive to fine cracks formed during exposure to temperature; the effect of

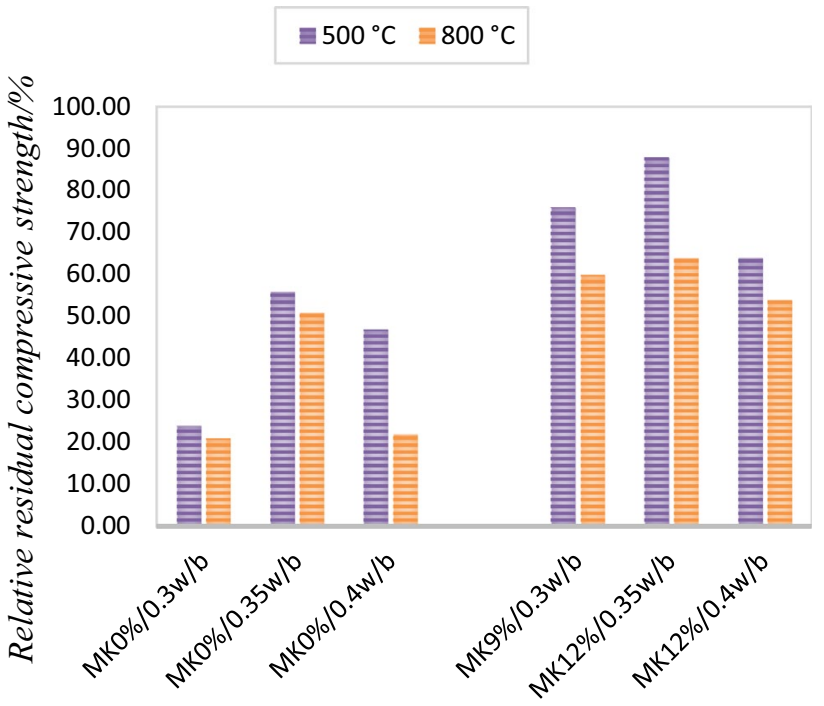

Fig. 14 Comparison between mixtures that contain $0 \%$ of MK, and the optimum dosages of the three $w / b$ ratios

MK on the bending strength is still narrow and in dispute. The standard deviation values are summarized in Table 6 .

For all w/b ratio, the relative residual bending strength (RRBS) is decreased with increasing temperatures. Figure 15 shows the RRBS of mixtures with $0.3 \mathrm{w} / \mathrm{b}$ ratio

The values of RRBS of all mixtures that contain MK are higher than the pure OPC as shown in Fig. 15. From results, $9 \%$ and $12 \%$ replacements of cement by MK improve the bending strength. Meanwhile, Hong et al. [49] reported that the bending strength increases by increasing MK amount between $10 \%$ and $15 \%$ replacements.

Figures 16 and 17 present the RRBS for mixtures of 0.35 and $0.4 \mathrm{w} / \mathrm{b}$, respectively. The efficiency appears to increase up to $12 \%$ of MK replacement, similar to the trend observed for residual compressive results. However, $12 \%$ of MK could be accepted as an optimum replacement from the perspective of high temperature resistance. Finally, MK enhances the bending capacity after exposure to high temperatures by increasing the amount of hydration products as well as by acting as a fibre that helps to bridge the microcracks [50].

The difference between the optimum dosages of ambient and elevated temperatures is attributed to an important reason; the heat curing helps the reaction between the unreacted MK with cement. In addition, the importance of decreasing the $\mathrm{Ca}(\mathrm{OH})_{2}$, which is achieved by the increase in $\mathrm{MK}$ amount, is clear at high temperatures.

Generally, prisms show more disintegration and cracking and some cases partial spalling and then cubes like prism of $0 \% \mathrm{MK}$ at elevated temperature. This phenomenon is commonly referred to as "size effect", and this is due to the fact that specimen size has a direct influence on the rate of heat and loss of moisture and moisture content at testing time. 
Table 5 Values of residual bending strength at $20^{\circ} \mathrm{C}(\mathrm{MPa})$

\begin{tabular}{lclllll}
\hline $\mathrm{w} / \mathrm{b}$ & MK 0\% & MK 3\% & MK 6\% & MK 9\% & MK 12\% & MK 15\% \\
\hline 0.3 & 5.9 & 6.03 & 3.27 & 1.87 & 1.77 & 2.22 \\
0.35 & 7.3 & 1.97 & 1.13 & 8.69 & 2.97 & 7.58 \\
0.4 & 11.53 & 4.36 & 4.06 & 6.05 & 4.88 & 4.64 \\
\hline
\end{tabular}

Table 6 Standard deviation of bending strength values

\begin{tabular}{|c|c|c|c|c|c|c|}
\hline & MK 0\% & MK 3\% & MK 6\% & MK 9\% & MK $12 \%$ & MK $15 \%$ \\
\hline \multicolumn{7}{|l|}{$0.3 \mathrm{w} / \mathrm{b}$} \\
\hline $20^{\circ} \mathrm{C}$ & 0.27 & 1.21 & 0.03 & 0.41 & 0.25 & 0.36 \\
\hline $50{ }^{\circ} \mathrm{C}$ & 1.36 & 0.40 & 0.90 & 0.09 & 0.58 & 0.09 \\
\hline $150^{\circ} \mathrm{C}$ & 2.17 & 0.60 & 0.39 & 0.59 & 0.67 & 1.01 \\
\hline $300^{\circ} \mathrm{C}$ & 0.37 & 0.43 & 0.27 & 0.07 & 0.51 & 0.27 \\
\hline $400^{\circ} \mathrm{C}$ & 0.72 & 0.24 & 0.11 & 0.44 & 0.17 & 0.39 \\
\hline $500^{\circ} \mathrm{C}$ & 0.21 & 0.23 & 0.29 & 0.18 & 0.48 & 0.02 \\
\hline $800^{\circ} \mathrm{C}$ & 0.05 & 0.12 & 0.06 & 0.25 & 0.28 & 0.19 \\
\hline $900^{\circ} \mathrm{C}$ & 0.17 & 0.14 & 0.09 & 0.14 & 0.05 & 0.15 \\
\hline \multicolumn{7}{|l|}{$0.35 \mathrm{w} / \mathrm{b}$} \\
\hline $20^{\circ} \mathrm{C}$ & 1.51 & 0.09 & 0.31 & 1.30 & 0.99 & 1.48 \\
\hline $50^{\circ} \mathrm{C}$ & 0.63 & 0.32 & 0.44 & 0.17 & 0.11 & 1.36 \\
\hline $150^{\circ} \mathrm{C}$ & 0.17 & 0.74 & 0.83 & 0.17 & 0.24 & 0.86 \\
\hline $300^{\circ} \mathrm{C}$ & 0.15 & 1.41 & 0.87 & 0.22 & 0.22 & 0.20 \\
\hline $400^{\circ} \mathrm{C}$ & 0.93 & 0.26 & 0.23 & 0.21 & 0.22 & 0.62 \\
\hline $500^{\circ} \mathrm{C}$ & 0.06 & 0.80 & 0.11 & 0.83 & 0.81 & 0.25 \\
\hline $800^{\circ} \mathrm{C}$ & 0.02 & 0.14 & 0.08 & 0.13 & 0.33 & 0.23 \\
\hline \multicolumn{7}{|l|}{$0.4 \mathrm{w} / \mathrm{b}$} \\
\hline $20^{\circ} \mathrm{C}$ & 1.19 & 0.52 & 0.96 & 0.28 & 0.20 & \\
\hline $50{ }^{\circ} \mathrm{C}$ & 0.30 & 0.34 & 0.15 & 0.22 & 0.47 & 0.92 \\
\hline $150^{\circ} \mathrm{C}$ & 0.43 & 0.04 & 0.14 & 0.30 & 0.37 & 0.35 \\
\hline $300^{\circ} \mathrm{C}$ & 0.76 & 0.47 & 0.98 & 0.30 & 1.29 & 0.33 \\
\hline $400^{\circ} \mathrm{C}$ & 0.39 & 0.82 & 0.38 & 0.12 & 0.53 & 0.92 \\
\hline $500^{\circ} \mathrm{C}$ & 0.17 & 0.14 & 0.90 & 1.03 & 0.32 & 0.65 \\
\hline $800^{\circ} \mathrm{C}$ & 0.01 & 0.05 & 0.22 & 0.15 & 0.69 & 0.07 \\
\hline $900^{\circ} \mathrm{C}$ & 0.24 & 0.34 & 0.01 & 0.15 & 0.14 & 0.17 \\
\hline
\end{tabular}

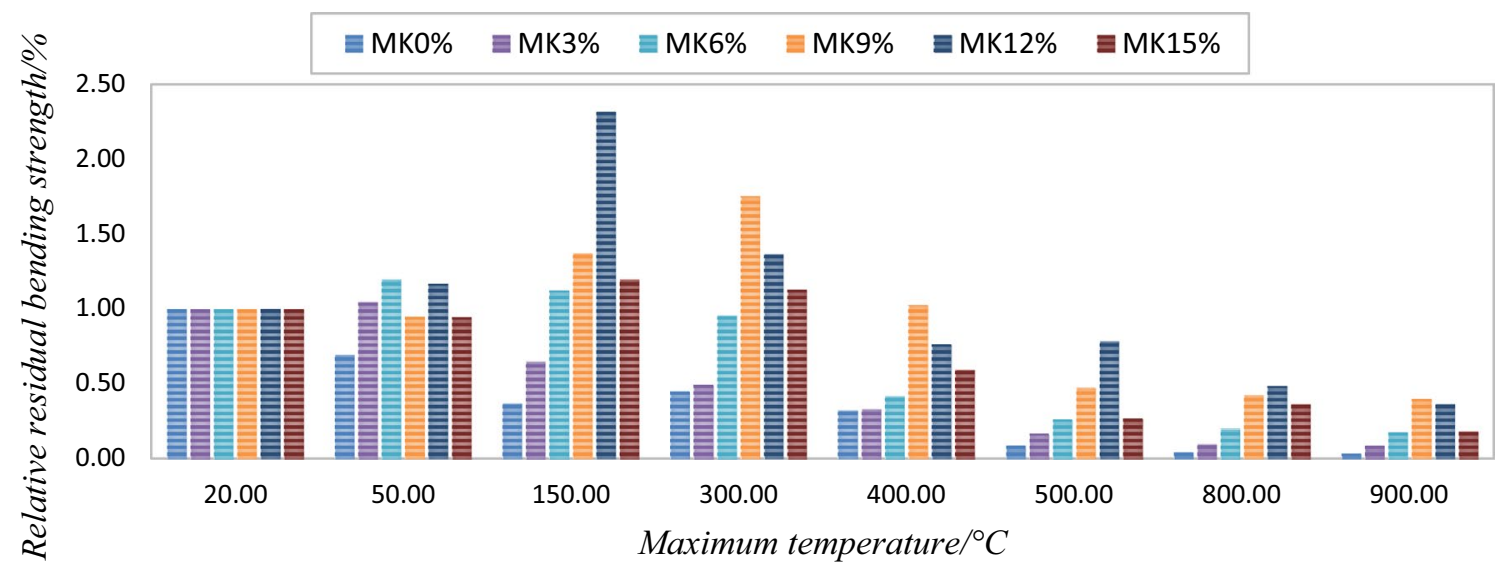

Fig. 15 Relative residual bending strength as a function of temperature of mixtures incorporated with MK of $0.3 \mathrm{w} / \mathrm{b}$ 


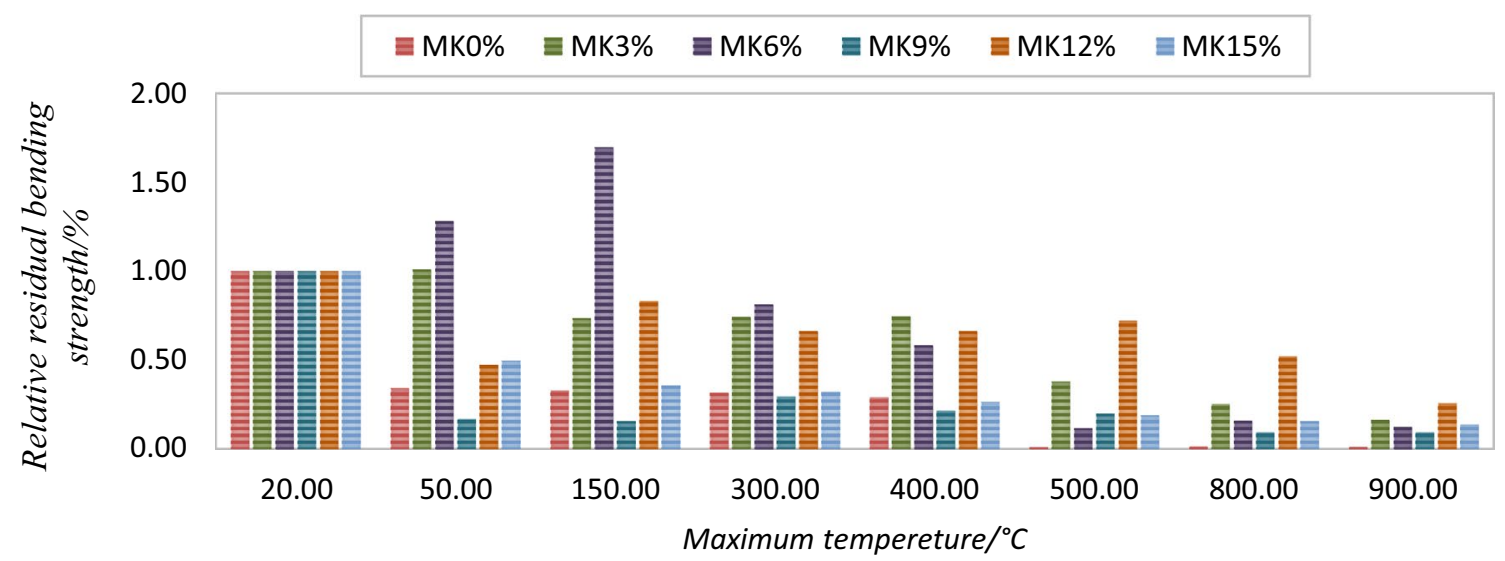

Fig. 16 Relative residual bending strength as a function of temperature of mixtures incorporated with MK of 0.35 w/b

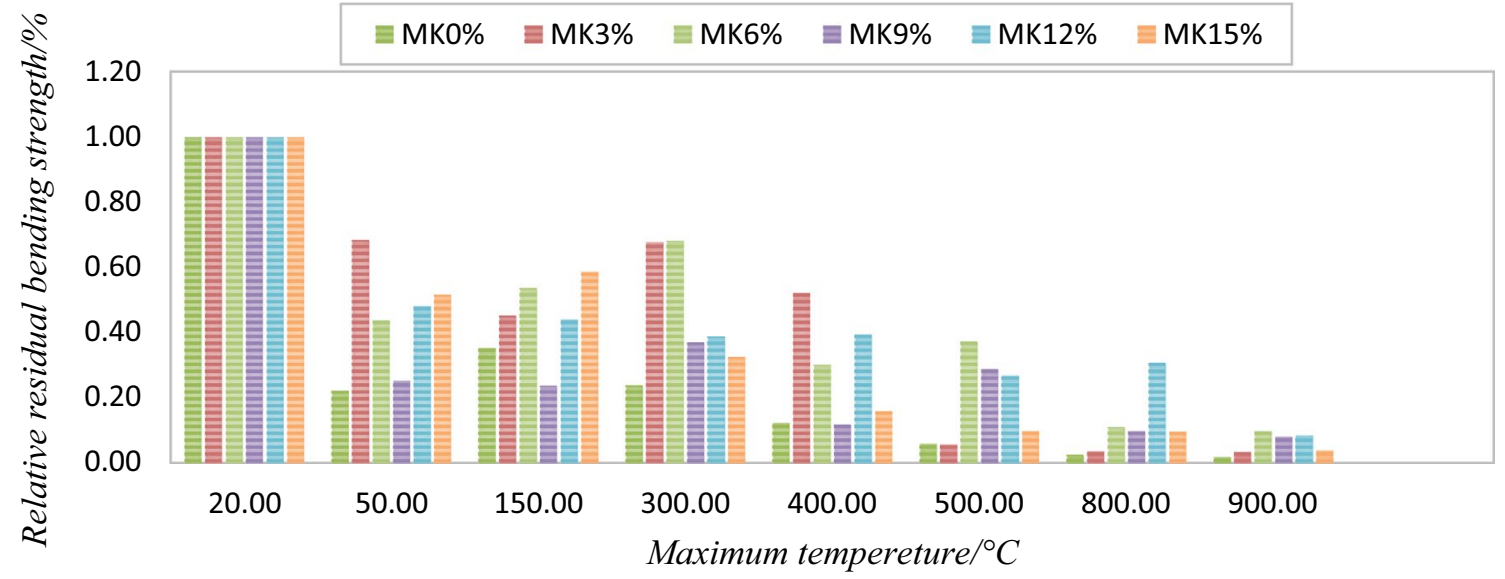

Fig. 17 Relative residual bending strength as a function of temperature of mixtures incorporated with MK of $0.4 \mathrm{w} / \mathrm{b}$

For instance, a smaller size specimen provides a shorter path for moisture to escape during the high temperature test, thereby reducing spalling or cracking stresses [51].

\section{Thermogravimetric results}

The mass loss and derivative mass loss curves in the range $20-900{ }^{\circ} \mathrm{C}$ for the samples of MK with $0.35 \mathrm{w} / \mathrm{b}$ are summarized in Fig. 18 illustrating the TGA/DTG of MK mixtures of $0.35 \mathrm{w} / \mathrm{b}$. As shown in TGA/DTG results, there are three peaks representing mass losses with temperatures. It can be seen that the first peak is between 20 and $200{ }^{\circ} \mathrm{C}$. This peak is mainly due to evaporation of moisture, which is higher with MK samples than the sample without MK. The second endothermic peak, between 430 and $540{ }^{\circ} \mathrm{C}$, is due to loss of water from $\mathrm{Ca}(\mathrm{OH})_{2}$. Loss of mass decreases with the increase in MK content, and this is due to the consumed $\mathrm{Ca}(\mathrm{OH})_{2}$ amount by MK. Finally, the third endothermic peak appears in the range of 600 and $900{ }^{\circ} \mathrm{C}$ corresponding to

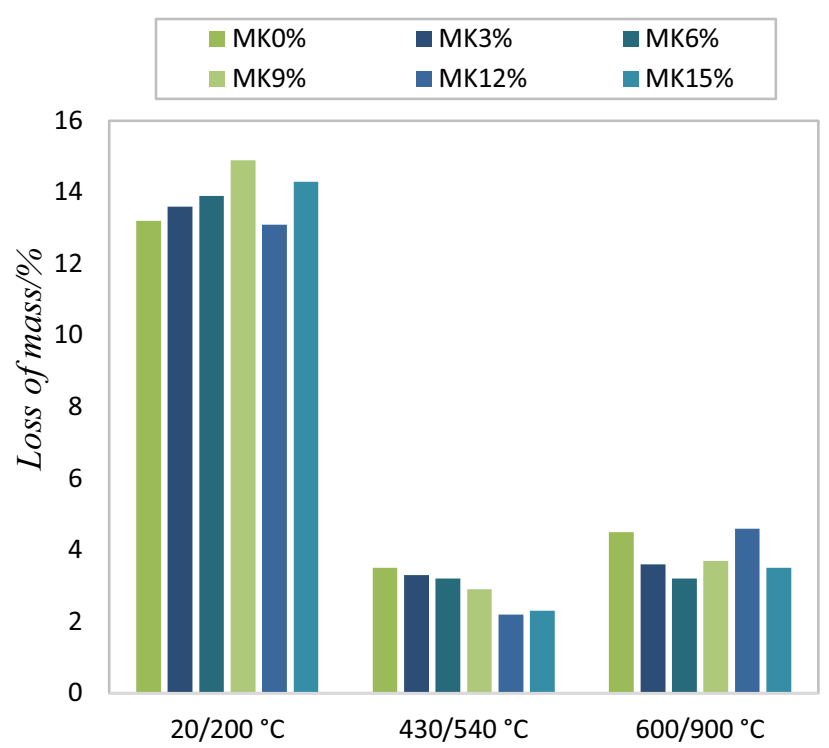

Fig. 18 TGA/DTG of MK samples with 0.35 w/b 
Fig. 19 The SEM pictures of pure and pozzolanic cement pastes microstructures at 20 and $500{ }^{\circ} \mathrm{C}$
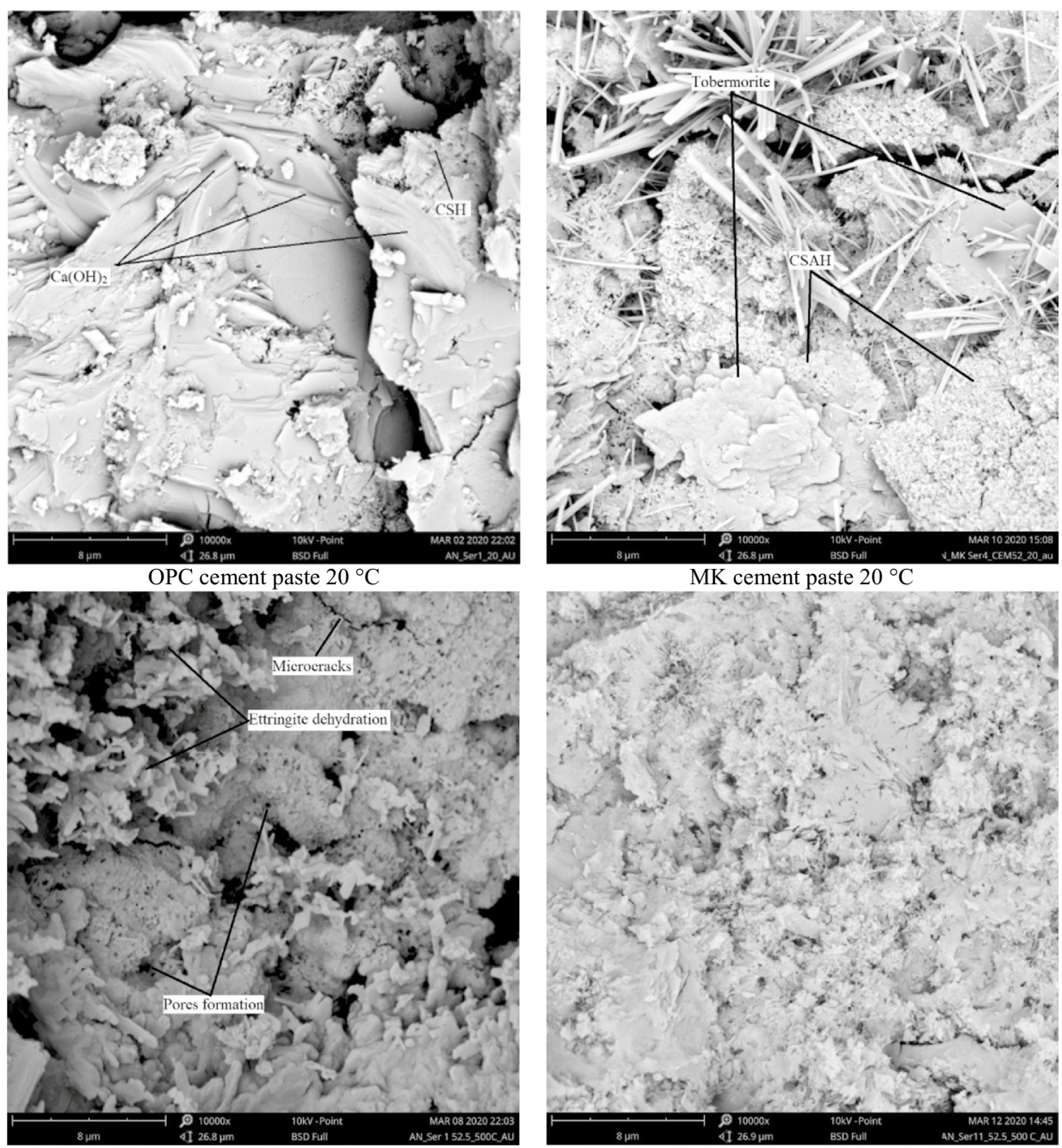

OPC cement paste $500{ }^{\circ} \mathrm{C}$

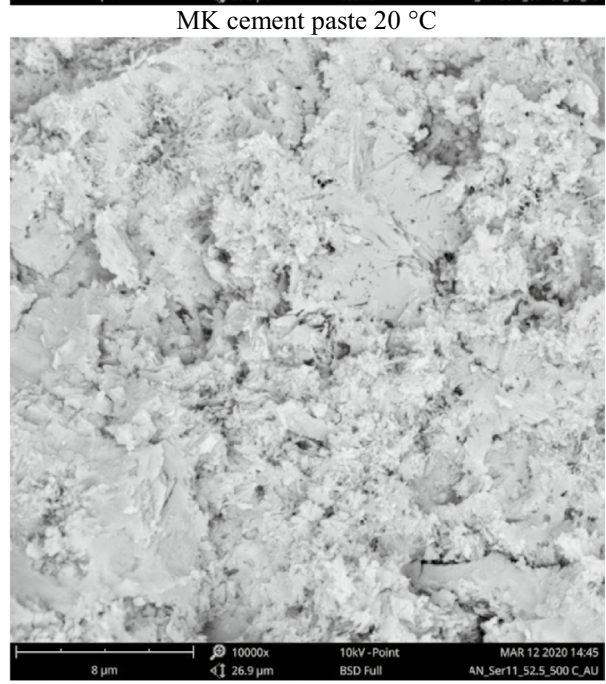

MK cement paste $500{ }^{\circ} \mathrm{C}$ the loss of water from the decomposition of CSH and the loss of $\mathrm{CO}_{2}$ from the carbonation product. In this study, the second peak is considered to be crucial due to the harmful effect of $\mathrm{Ca}(\mathrm{OH})_{2}$ at higher temperatures. The TG results are matching with compressive and bending strength results in Figs. 10 and 16, respectively.

\section{Microstructure observation}

Figure 19 shows the SEM images of the hardened paste of pure OPC and with $\mathrm{MK}$ at $20^{\circ} \mathrm{C}$ and after the exposure to $500{ }^{\circ} \mathrm{C}$. In case of results at $20^{\circ} \mathrm{C}$, the pure OPC paste contains a lot of hexagonal $\mathrm{Ca}(\mathrm{OH})_{2}$. In the other hand, paste contains MK showing a high CSH and CSAH. The physical property at ambient temperatures paste containing pozzolans shows denser microstructure than the pure cement paste.

According to the SEM images at $500{ }^{\circ} \mathrm{C}$, results show a lot of pores and destruction in the microstructure of the pure OPC paste at elevated temperatures. Meanwhile, paste containing MK still shows denser microstructures at elevated temperatures. This is due to the decrease in $\mathrm{Ca}(\mathrm{OH})_{2}$ content and the increase in CSAH content which fills and makes refinement of pores and keeps the structure coherent. The major problem causing the deterioration of cement paste at elevated temperatures is the decomposition of $\mathrm{Ca}(\mathrm{OH})_{2}$, where its presence in the pure cement paste is about $28 \%$ of its own mass [52]. Consequently, the cement pastes blended with pozzolans exhibited higher capacities than pure cement paste.

\section{Conclusions}

The main goal of the present study is to evaluate the behaviour of MK pastes with different $w / b$ ratios before and after exposed to elevated temperatures. Possible improvements on 
the mechanical properties of high-strength paste are clear. Different MK replacements were used, i.e. 0, 3, 6, 9, 12, and $15 \%$ of the cement masses were exposed to temperatures 20 , $50,150,300,400,500,800$, and $900{ }^{\circ} \mathrm{C}$. This experimental study also covered an analysis of post-heating characteristics of hardened cement paste. From the results, the following conclusions can be drawn:

- Optimum dosages of MK, at ambient temperature, were $12 \%, 6 \%$, and $6 \%$ in cement paste with w/b of $0.3,0.35$, and 0.4 , respectively.

- According to the relative residual compressive strength, 9\% of MK content has the highest value among other ratio at high temperatures for $\mathrm{w} / \mathrm{b}$ ratio of 0.3 .

- According to the relative residual compressive strength, $12 \%$ of MK content has the highest value among other ratio at high temperatures for $\mathrm{w} / \mathrm{b}$ ratio of both 0.35 and 0.4 .

- The optimum relative residual bending strengths have been obtained in the ranges of MK replacement level in accordance with results of relative residual compressive strengths.

- MK has significant influence on surface cracks due to elevated temperatures. The more the paste contains MK, the less the cracks occur.

- Excessively increasing the amount of MK leads to increase in the probability of spalling.

- Different amounts of w/b ratio have significant effect on optimum MK dosage at both ambient and elevated temperatures.

- The risk of spalling was higher for prisms than for cubes, which could be explained according to the different shapes and sizes of the specimens.

\section{Recommendations}

MK is a very beneficial material, and it has the capacity to enhance the transition zone due to its fineness. The inclusion of MK with recycled aggregate could enhance the weakness and improve the bond of cement paste with recycled aggregate.

Acknowledgements Open access funding provided by Budapest University of Technology and Economics. This research was carried out with the support of the Bolyai János Scholarships. The research was supported by the Higher Education Institutional Excellence Program, under the topic program of the BME FIKP-WATER, announced by the Ministry of Human Resources, and also supported by the UNKP19-4 New National Excellence program of the Ministry for Innovation and Technology. Authors acknowledge the support by the Hungarian Research Grant NVKP 16-1-0019 "Development of concrete products with improved resistance to chemical corrosion, fire or freeze-thaw".

Open Access This article is licensed under a Creative Commons Attribution 4.0 International License, which permits use, sharing, adaptation, distribution and reproduction in any medium or format, as long as you give appropriate credit to the original author(s) and the source, provide a link to the Creative Commons licence, and indicate if changes were made. The images or other third party material in this article are included in the article's Creative Commons licence, unless indicated otherwise in a credit line to the material. If material is not included in the article's Creative Commons licence and your intended use is not permitted by statutory regulation or exceeds the permitted use, you will need to obtain permission directly from the copyright holder. To view a copy of this licence, visit http://creativecommons .org/licenses/by/4.0/.

\section{References}

1. Kostuch JA, Walters V, Jones TR. High performance concretes incorporating metakaolin: a review. In: Dhir RK, Jones MR, editors. Concrete 2000, economic and durable construction through excellence. London: E\&FN Spon; 1993. p. 1799-811.

2. Caldarone MA, Gruber KA, Burg RG. High reactivity metakaolin (HRM): a new generation mineral admixture for high performance concrete. Concr Int. 1994;16(11):37-41.

3. Sabir BB, Wild S, Khatib JM. On the workability and strength development of metakaolin concrete. In: Dyer TD, Dhir RK, editors. Concrete for environmental enhancement and protection. London: E\&FN Spon; 1996. p. 651-6.

4. Zhang MH, Malhotra VM. Characteristics of a thermally activated alumino-silicate pozzolanic material and its use in concrete. Cem Concr Res. 1995;25(8):1713-25.

5. Curcio F, DeAngelis BA, Pagliolico S. Metakaolin as a pozzolanic microfiller for high-performance mortars. Cem Concr Res. 1998;28(6):803-9.

6. Saad MN, DeAndrade WP, Paulon VA. Properties of mass concrete containing an active pozzolan made from clay. Concr Int. 1982;4(7):59-65.

7. Poon CS, Lam L, Kou SC, Wong YL, Wong R. Rate of pozzolanic reaction of metakaolin in high-performance cement pastes. Cem Concr Res. 2001;31(9):1301-6.

8. Poon CS, Azhar S, Anson M, Wong YL. Performance of metakaolin concrete at elevated temperatures. Cem Concr Compos. 2003;25(1):83-9.

9. Hoff GC, Bilodeau A, Malhotra VM. Elevated temperature effects on HSC residual strength. Concr Int. 2000;22(4):41-8.

10. Chan SY, Peng GF, Chan JK. Comparison between high strength concrete and normal strength concrete subjected to high temperature. Mater Struct. 1996;29(10):616-9.

11. Khoury G, Anderberg Y, Both K, Fellinger J, Hoj NP, Majorana C. Fire design of concrete structures-materials, structures and modelling. State of art report Guidelines of FIB-CEB-FIP. Task Group 4-3, Bulletin 38, ISSN 1562-3610. 2007.

12. Xu Y, Wong YL, Poon CS, Anson M. Impact of high temperature on PFA concrete. Cem Concr Res. 2001;31(7):1065-73.

13. Tanyildizi H, Coskun A. The effect of high temperature on compressive strength and splitting tensile strength of structural lightweight concrete containing fly ash. Constr Build Mater. 2008;22(11):2269-75.

14. Demirboğa R, Türkmen İ, Karakoç MB. Thermo-mechanical properties of concrete containing high-volume mineral admixtures. Build Environ. 2007;42(1):349-54.

15. Aydin S. Development of a high-temperature-resistant mortar by using slag and pumice. Fire Saf J. 2008;43(8):610-7.

16. Wang HY. The effects of elevated temperature on cement paste containing GGBFS. Cem Concr Comp. 2008;30(10):992-9. 
17. Morsy MS, Alsayed SH, Aqel M. Effect of elevated temperature on mechanical properties and microstructure of silica flour concrete. Int J Civ Eng. 2010;10(1):1-6.

18. Feldman RF, Ramachandran VS. Differentiation of interlayer and adsorbed water in hydrated Portland cement by thermal analysis. Cem Concr Res. 1971;1(6):607-20.

19. Nadeem A, Memon SA, Lo TY. Qualitative and quantitative analysis and identification of flaws in the microstructure of fly ash and metakaolin blended high performance concrete after exposure to elevated temperatures. Constr Build Mater. 2013;1(38):731-41.

20. Hager I. Behaviour of cement concrete at high temperature. Bull Polish Acad Sci Tech Sci. 2013;61(1):145-54.

21. Taylor HF. Cement chemistry. London: Thomas Telford Services Ltd; 1997.

22. Peng GF, Huang ZS. Change in microstructure of hardened cement paste subjected to elevated temperatures. Constr Build Mater. 2008;22(4):593-9.

23. Kodur VK, Sultan MA. Effect of temperature on thermal properties of high-strength concrete. J Mater Civ Eng. 2003;15(2):101-7.

24. Demirel B, Keleştemur O. Effect of elevated temperature on the mechanical properties of concrete produced with finely ground pumice and silica fume. Fire Saf J. 2010;45(6-8):385-91.

25. Aydin S, Baradan B. Effect of pumice and fly ash incorporation on high temperature resistance of cement based mortars. Cem Concr Res. 2007;37(6):988-95.

26. Lea FC. The resistance to fire of concrete and reinforced concrete. J Soc Chem Ind. 1922;30;41(18):395R-6R.

27. Ghosh SN, Sarkar SL, Harsh S. Mineral admixtures in cement and concrete. Tiruchirappalli: Abi Books; 1993.

28. Dinakar P, Sahoo PK, Sriram G. Effect of metakaolin content on the properties of high strength concrete. Inter J Concr Struct Mater. 2013;7(3):215-23.

29. Khatib JM. Metakaolin concrete at a low water to binder ratio. Constr Build Mater. 2008;22(8):1691-700.

30. El-Diadamony H, Amer AA, Sokkary TM, El-Hoseny S. Hydration and characteristics of metakaolin pozzolanic cement pastes. Housing Build Natio Res Center J. 2018;14(2):150-8.

31. Morsy MS, Rashad AM, El-Nouhy HA. Effect of elevated temperature on physico-mechanical properties of metakaolin blended cement mortar. Struct Eng Mech. 2009;31(1):1.

32. MSZ EN 196-2 Cement testing methods. Part 2: Chemical Analysis of cement. Budapest: Magyar Szabva’nyu“"gyi Testu“let;2013 (in Hungarian).

33. MSZ EN 525-12 Chemical analysis of cement. Part 12: determination of free lime content. Budapest: Magyar Szabványügyi Testület; 2014 (in Hungarian).

34. BS EN 12620:2002 + A1. Aggregates for concrete. London: British Standards Institution; 2008.

35. MSZ 4798. Hungarian standard of working community of concrete and cement manufacturers. 2015.
36. Heikal M. Characteristics, textural properties and fire resistance of cement pastes containing $\mathrm{Fe}_{2} \mathrm{O}_{3}$ nano-particles. J Therm Anal Calorim. 2016;126(3):1077-87.

37. Farzadnia N, Ali AA, Demirboga R, Anwar MP. Characterization of high strength mortars with nano Titania at elevated temperatures. Constr Build Mater. 2013;1(43):469-79.

38. Abed M, Nemes R, Lubloy E. The impact of time on the heat resistance of self-compacting high-performance concrete incorporated with recycled materials. J Therm Anal Colorim. 2019;138(1):35-45.

39. RILEM Technical Committees 129-MHT. Test methods for mechanical properties of concrete at high temperatures, part 1: introduction, part 2: stress-strain relation, part 3: compressive strength for service and accident conditions. Mater Struct. 1995;28(181):410-4.

40. Eckart A, Ludwig HM, Stark J. Hydration of the 4 main portlandcement clinker phases. Zement-Kalk-Gips. 1995;48(8):443-52.

41. ISO-834. Fire resistance test-elements of building construction, International Standard ISO384, Geneva, Switzerland, 1975.

42. Dabhade AN, Choudhari SR, Gajbhiye AR. Performance evaluation of recycled aggregate used in concrete. Int J Eng Res Appl (IJERA). 2012;2(4):1387.

43. Caldarone MA. High-strength concrete: a practical guide. Cambridge: CRC Press; 2008.

44. Wild S, Khatib JM, Jones A. Relative strength, pozzolanic activity and cement hydration in superplasticised metakaolin concrete. Cem Concr Res. 1996;26(10):1537-44.

45. Khatib JM, Clay RM. Absorption characteristics of metakaolin concrete. Cem Concr Res. 2004;34(1):19-29.

46. Roy DM, Gouda GR. Porosity-strength relation in cementitious materials with very high strengths. J Am Ceramic Soc. 1973;56(10):549-50.

47. Chanvillard G. The concrete material: General knowledge. Aĺeas. 1999;33:115-39.

48. Ollivier JP, Buil M. Concrete design: the porous structure. In: The durability of concrete. Presses of l'ENPC, editors. Paris, 1992.

49. Kim HS, Lee SH, Moon HY. Strength properties and durability aspects of high strength concrete using Korean metakaolin. Constr Build Mater. 2007;21(6):1229-37.

50. Morsy MS, Al-Salloum YA, Abbas H, Alsayed SH. Behavior of blended cement mortars containing nano-metakaolin at elevated temperatures. Constr Build Mater. 2012;1(35):900-5.

51. Erdem TK. Specimen size effect on the residual properties of engineered cementitious composites subjected to high temperatures. Cem Concr compos. 2014;45:1-8.

52. Sabir BB, Wild S, Bai J. Metakaolin and calcined clays as pozzolans for concrete: a review. Cem Concr Compos. 2001;23(6):441-54.

Publisher's Note Springer Nature remains neutral with regard to jurisdictional claims in published maps and institutional affiliations. 